RESTORING RELIGIOUS FREEDOM TO THE WORKPLACE: TITLE VII, RFRA AND RELIGIOUS ACCOMMODATION

\author{
SIDNEY A. ROSENZWEIG $†$
}

\title{
INTRODUCTION
}

Clashes between employers and employees over religious observance in the workplace are an increasingly familiar feature in the legal system. Accordingly, employees filed nearly 3000 charges of religious discrimination with the federal Equal Employment Opportunity Commission ("EEOC") and with state and local agencies in 1994-an increase of over thirty percent from 1990. ${ }^{1}$ Many of these complaints involved employers' failures to accommodate the religious beliefs of their employees.

The case law abounds with examples of the types of religious observance for which employees might require accommodation. For instance, the complaining employee may be a Sabbatarian, unable to work on Saturdays or on Sundays. ${ }^{2}$ Alternatively, she may need to

† Sc.B., Brown University, 1993; J.D., University of Pennsylvania, 1996. Special thanks go out to Judge Arlin Adams, Professors Frank Goodman and Eugene Volokh, and my peers Michael Baughman, David Elchoness and Chevanniese Smith for their comments on earlier drafts.

1 See Margaret A. Jacobs, Courts Wrestle with Religion in Workplace, WaLL ST. J., Oct. 10, 1995, at B1; see also Debbie N. Kaminer \& Harlan A. Loeb, Guidance Is Lacking on Religious Accommodation, NAT'L L.J., Nov. 13, 1995, at C8, C8 ("As religion in pluralistic America searches for its place, religious discrimination in employment is beginning to emerge from the shadows of sexual harassment, affirmative action remedies and wrongful termination in the panoply of Title VII claims that are filling the dockets.").

2 See, e.g., Estate of Thornton v. Caldor, Inc., 472 U.S. 703 (1985); TWA v. Hardison, 432 U.S. 63 (1977); Genas v. Department of Correctional Servs., No. 957125 , 1996 U.S. App. LEXIS 2080, at $* 13$ (2d Cir. Feb. 12, 1996); Beadle v. City of Tampa, 42 F.3d 633 (11th Cir.), cert. denied, 115 S. Ct. 2600 (1995); Beadle v. Hillsborough County Sheriff's Dep't, 29 F.3d 589 (11th Gir. 1994), cert. denied, 115 S. Ct. 2001 (1995); Benton v. Carded Graphics, Inc., 28 F.3d 1208, No. 93-1675, 1994 WL 249221 (4th Cir. June 9, 1994) (unpublished table decision); Lee v. ABF Freight Sys., Inc., 22 F.3d 1019 (10th Cir. 1994); Cooper v. Oak Rubber Co., 15 F.3d 1375 (6th Cir. 1994); Mann v. Frank, 7 F.3d 1365 (8th Cir. 1993); Blair v. Graham Correctional Ctr., 4 F.3d 996, No. 92-1597, 1993 WL 331886 (7th Cir. Sept. 1, 1993) (unpublished table decision), cert. denied, 114 S. Ct. 924 (1994); Wright v. Runyon, 2 F.3d 214 (7th Cir.), cert. denied, 114 S. Ct. 1077 (1993); Smith v. Pyro Mining Co., 827 F.2d 1081 (6th Cir. 1987), cert. denied, 485 U.S. 989 (1988); Protos v. Volkswagen of Am., Inc., 797 F.2d 129 (3d Cir.), cert. denied, 479 U.S. 972 (1986); Brener v. Diagnostic Ctr. Hosp., 671 F.2d 141 (5th Cir. 1982); Brown v. General Motors Corp., 601 F.2d 956 (8th Cir. 1979); Ward v. Allegheny Ludlum Steel Corp., 560 F.2d 579 (3d Cir. 1977). 
observe occasional holidays ${ }^{3}$ or attend religious functions. ${ }^{4}$ Her religion may require her to wear certain garb or maintain a certain appearance, in conflict with an employer's dress code. ${ }^{5}$ She may object to attending mandatory meetings in which her employer conducts devotional services or exercises, ${ }^{6}$ or, in the converse, may wish to conduct such services herself. ${ }^{7}$ She may oppose medical diagnosis and treatment, which results in her above-average use of sick days. ${ }^{8}$ Her beliefs may require that she live in a community with an active church of her denomination. ${ }^{9}$ She may oppose having to sleep in the same room with a member of the opposite sex while on duty. $^{10}$ Her opposition to violence may render her unable to perform occasional occupational tasks, ${ }^{11}$ or her religion may

${ }^{3}$ See, e.g., Ansonia Bd. of Educ. v. Philbrook, 479 U.S. 60, 62-63 (1986) (school teacher's religious beliefs required her to refrain from employment on designated holy days causing her to miss more school days than allotted by the school board for observance of religious holidays); Webb v. Baxter Healthcare Corp., 57 F.3d 1067, No. 941784, 1995 WL 352485 (4th Cir. June 13, 1995) (unpublished table decision) (employer denied sales representative's request for time off in observance of Yom Kippur and Passover).

${ }^{4}$ See, e.g., Heller v. EBB Auto Co., 8 F.3d 1433, 1437 (9th Cir. 1993) (employee's attendance of the joint B'nai Mitzvah of his wife and son caused him to be fired because he missed a mandatory meeting); DePriest v. Department of Human Servs., 830 F.2d 193, No. 86-5920, 1987 WL 44454, at *3 (6th Cir. Oct. 1, 1987) (unpublished table decision) (employee's insistence on attending religious services led to the termination of her employment); Howard v. Haverty Furniture Cos., 615 F.2d 203, 205 (5th Cir. 1980) (part-time Methodist minister's absence from warehousing job to officiate at funeral resulted in his discharge); Redmond v. GAF Corp., 574 F.2d 897, 899 (7th Cir. 1978) (employee's inability to work Saturday overtime due to Bible-study class attendance resulted in termination).

${ }^{5}$ See, e.g., Wilson v. U.S. West Communications, 58 F.3d 1337, 1339 (8th Cir. 1995) (employee's button with graphically depicted aborted fetus created tremendous disruptions among co-workers, resulting in diminished productivity); United States v. Board of Educ., 911 F.2d 882, 894 (3d Cir. 1990) (female school teacher's Muslim religious garb not permitted under Pennsylvania law); Bhatia v. Chevron U.S.A., Inc., 734 F.2d 1382, 1383 (9th Cir. 1984) (male Sikh employee could not shave his beard for religious reasons, inhibiting his ability to use a respirator in the event of an accidental exposure to toxic gases).

${ }^{6}$ See EEOC v. Townley Eng'g \& Mfg. Co., 859 F.2d 610 (9th Cir.), cert. denied, 489 U.S. 1077 (1989); Young v. Southwestern Sav. and Loan Ass'n, 509 F.2d 140 (5th Cir. 1975).

7 See Brown v. Polk County, 61 F.3d 650 (8th Cir. 1995) (en banc).

${ }^{8}$ See Riselay v. Secretary of Health \& Human Servs., 929 F.2d 701, No. 90-1779, 1991 WL 44319 (6th Cir. Apr. 2, 1991) (unpublished table decision) (Christian Scientist's above-average use of sick-leave prompted employer to require documentation to support future sick-leave).

${ }^{9}$ See Vetter v. Farmland Indus., 901 F. Supp. 1446, 1449 (N.D. Iowa 1995).

${ }^{10}$ See Miller v. Drennon, 966 F.2d 1443, No. 91-2166, 1992 WL 137578 (4th Cir. June 19, 1992) (unpublished table decision) (male EMS worker working 24-hour shifts required to sleep in EMS substation with female co-worker).

${ }_{11}$ See, e.g., Ryan v. United States Dep't of Justice, 950 F.2d 458 (7th Cir. 1991) (FBI 
prohibit the use of her social security number. ${ }^{12}$ Perhaps she is fundamentally opposed to affiliation with labor organizations, ${ }^{13}$ or more narrowly, objects to such affiliation based on particular activities undertaken by her local union. ${ }^{14}$ Her religious beliefs may proscribe mandatory donation to charity. ${ }^{15}$ Her worship may involve the use of controlled substances in violation of her employer's policies, ${ }^{16}$ or as in the most celebrated case of recent months, she may object to standing at work during the national anthem. ${ }^{17}$

Some expressions of religious belief require more accommodation than others. Title VII of the Civil Rights Act of 1964 sets the standard that determines whether employers must provide certain accommodations, or whether they may dismiss or discipline workers when the employee's religious requirements would be too burdensome to accommodate. ${ }^{18}$ The Court has narrowly interpreted the statutory test of "undue hardship," ${ }^{19}$ permitting the employer to discharge the employee either when the employee's exercise of her

employee refused to investigate destruction of government property by anti-war groups), cert. denied, 504 U.S. 958 (1992); American Postal Workers Union, San Francisco Local v. Postmaster Gen., 781 F.2d 772 (9th Cir. 1986) (postal worker opposed to violence unable to process draft applications).

${ }_{12}$ See, e.g., Hover v. Florida Power \& Light Co., No. 93-14236, 1995 WL 91531 (S.D. Fla. Feb. 6, 1995) ("[T] he Plaintiff alleges that his religious beliefs prevent him from using his social security number as 'the mark of the beast' and therefore is not required to give that information to any employer ....").

${ }^{13}$ See, e.g., McDaniel v. Essex Int'l, Inc., 696 F.2d 34, 35 (6th Cir. 1982) (plaintiff discharged by employer at the behest of the local union for refusing to pay her dues); Tooley v. Martin-Marietta Corp., 648 F.2d 1239 (9th Cir.) (same), cert. denied, 454 U.S. 1098 (1981); Nottelson v. Smith Steel Workers, D.A.L.U. 19806, 643 F.2d 445 (7th Cir.) (same), cert. denied, 454 U.S. 1046 (1981); Burns v. Southern Pac. Transp. Co., 589 F.2d 403 (9th Cir. 1978) (same), cert. denied, 439 U.S. 1072 (1979).

${ }^{14}$ See EEOC v. University of Detroit, 904 F.2d 331, 332 (6th Cir. 1990) (employee objected to paying union dues where the union supported the pro-choice movement).

${ }^{15}$ See Yott v. North Am. Rockwell Corp., 602 F.2d 904 (9th Cir. 1979) (mandatory charity donation arose when employee refused to affiliate himself with labor organization because of religious beliefs), cert. denied, 445 U.S. 928 (1980).

${ }^{16}$ See, e.g., Employment Div. v. Smith, 494 U.S. 872 (1990) (employee discharged for sacramental use of peyote at a Native American church ceremony); Toledo v. Nobel-Sysco, Inc., 892 F.2d 1481 (10th Cir. 1989) (same), cert. denied, 495 U.S. 948 (1990).

${ }_{17}$ See, e.g., Jim Hodges, Abdul-Rauf Will Stand-and Pray, L.A. TIMES, Mar. 15, 1996, at $\mathrm{Cl}$ (professional basketball player refused to stand during the national anthem claiming it violated his Muslim beliefs); Manny Topol, Legal Issues Cloudy/Contract Law or Religion?, NEwSDAY, Mar. 14, 1996, at A95 (same).

${ }^{18}$ See Pub. L. No. 88-352, 78 Stat. 255 (codified as amended at 42 U.S.C. $\S 2000 \mathrm{e}(1994))$.

${ }^{19}$ See 42 U.S.C. $§ 2000 \mathrm{e}(\mathrm{j})(1994)$. 
religion poses more than a de minimis cost to the employer, or when accommodation would cause the employer to violate the law. ${ }^{20}$

The Religious Freedom Restoration Act of 1993 ("RFRA") prohibits the Government-federal, state or local-from substantially burdening an employee's free exercise of religion without a compelling interest and a showing that the intrusive law is narrowly tailored to achieve that compelling interest. ${ }^{21}$ Although RFRA does not directly modify the standards of Title VII, ${ }^{22}$ in an important class of cases it will have substantial effect.

RFRA creates a presumption that government regulation is unconstitutional when it substantially burdens an employee's religious exercise. No longer will an employer's reliance on complying with an otherwise valid law or regulation be the end of an inquiry into undue hardship. Instead, an employer's claim that some law within the Government's regulatory power constrains its ability to accommodate the employee triggers a RFRA analysis. Only if the employer-or the Government as intervenor-can sustain the law under RFRA as against the plaintiff-employee, is it reasonable for the employer to refuse to accommodate the employee. Title VII is not implicated by RFRA; instead, it is the labor law which "substantially burden [s] a person's exercise of religion. ${ }^{23}$

This Comment examines the requirements of Title VII in Part I. Then, in Part II, the attention turns to the Free Exercise Clause of the First Amendment, and RFRA's impact on First Amendment litigation in the context of employment discrimination. Last, Part III illustrates the analysis by examining the effect of RFRA on the most common area of Title VII religious-accommodation litigation, the inflexibility of seniority provisions of collective bargaining agreements to accommodate Sabbatarians. ${ }^{24}$ In doing so, this Comment will argue that RFRA is a landmark development for employees who allege that their employers fail to reasonably accommodate their religious beliefs and exercise.

${ }^{20}$ See TWA v. Hardison, 432 U.S. 63, 76-80, 84-85 (1977).

${ }^{21}$ See Pub. L. No. 103-141, 107 Stat. 1488 (codified at 42 U.S.C. $\S 2000$ bb to bb-4 (1994)).

${ }^{22}$ See S. REP. NO. 111, 103d Cong., 1st Sess. 13 (1993), reprinted in 1993 U.S.C.C.A.N. 1892, 1903 [hereinafter S. REP. No. 111] ("Nothing in this act shall be construed as affecting religious accommodation under title VII of the Civil Rights Act of $1964 . ")$.

${ }^{23} 42$ U.S.C. \$ $2000 \mathrm{bb}-1$ (a) (1994).

${ }^{24}$ See Cary v. Carmichael, 908 F. Supp. 1334, 1342 (E.D. Va. 1995) ("Sabbatarianism has been the most common religious belief causing conflict."). 


\section{TITLE VII}

Title VII of the Civil Rights Act of 1964 prohibits discrimination in employment on the basis of race, sex, religion and national origin. ${ }^{25}$ In cases of alleged religious discrimination, "[a]n employee establishes a prima facie case . . . by showing that: (1) the employee has a bona fide religious belief that conflicts with an employment requirement; (2) the employee informed the employer of this belief; (3) the employee was disciplined for failing to comply with the conflicting employment requirement." ${ }^{26}$ Once the employee establishes her prima facie case, the burden shifts to the employer to show either that it offered any "reasonable accommodation"-and not necessarily the employee's preferred accommodation ${ }^{27}$ - or that any potential accommodation would cause the employer "undue hardship."28

Despite the apparently forceful meaning of "undue hardship,"29 the Supreme Court has interpreted the term so as to dampen the

\footnotetext{
${ }^{25}$ For background on Title VI, see generally MACK A. PLAYER, EMPLOYMENT DisCRIMINATION LAW 199-210 (Practitioner's ed., 1988).

${ }^{26}$ Wilson v. U.S. West Communications, 58 F.3d 1337, 1340 (8th Cir. 1995); see also Ansonia Bd. of Educ. v. Philbrook, 479 U.S. 60, 65-66 (1986) (applying the same standard).

${ }^{27}$ See Ansonia, 479 U.S. at 68 ("[W]here the employer has already reasonably accommodated the employee's religious needs, the statutory inquiry is at an end. The employer need not further show that each of the employee's alternative accommodations would result in undue hardship.").

The employer and employee, however, do have a duty to cooperate to reach an amicable solution. See, e.g., id. at 69 ("Senator Randolph, the sponsor of ... [\$2000e(j)] expressed his hope that accommodation would be made with 'flexibility' and 'a desire to achieve an adjustment.' ... Consistent with these goals, courts have noted that 'bilateral cooperation is appropriate in the search for an acceptable reconciliation ....'") (citation omitted); Beadle v. Hillsborough County Sheriff's Dep't, 29 F.3d 589, 593 (11th Cir. 1994) ("While we recognize an employer's duty to reasonably accommodate the religious practices of its employee, we likewise recognize an employee's duty to make a good faith attempt to accommodate his religious needs through means offered by the employer."), cert. denied, 115 S. Ct. 2001 (1995); Lee v. ABF Freight Sys., Inc., 22 F.3d 1019, 1022 (10th Cir. 1994). ("The defendant's efforts to reach a reasonable accommodation triggered $\mathrm{Mr}$. Lee's duty to cooperate.").

${ }^{28} 42$ U.S.C. $\$ 2000 \mathrm{e}(\mathrm{j})$ (1994) ("The term 'religion' includes all aspects of religious observance and practice, as well as belief, unless an employer demonstrates that he is unable to reasonably accommodate to an employee's or prospective employee's religious observance or practice without undue hardship on the conduct of the employer's business."); see also Ansonia, 479 U.S. at 63 n.l.

29 See AMERICAN HERITAGE College DicTIONARY 619, 1473 (3d ed. 1993) (defining "hardship" as "[a] cause of privation or suffering" and "undue" as "[e]xceeding what is appropriate or normal"); see also 42 U.S.C. $\$ 12111$ (10)(A) (1994) (defining "undue hardship" for the purposes of the Americans with Disabilities Act of 1990 as "an action requiring significant difficulty or expense”).
} 
standard's force. ${ }^{30}$ As one commentator has stated: “The Title VII requirement that the secular employer reasonably accommodate the religious practices of the employee has been utterly minimized by the Court." ${ }^{31}$ The Court did this in TWA v. Hardison, ${ }^{32}$ in which it defined the monetary and nonmonetary thresholds that qualify as "undue."

\section{A. De Minimis Cost: Economics Causing Undue Hardship}

In dollar terms, the Hardison Court held that undue hardship represents anything more than de minimis cost. Following a voluntary transfer that caused Larry Hardison to lose his seniority under the collective bargaining agreement, his employer, TWA, forced him to work Saturdays when another employee went on vacation. $^{34}$ Hardison proffered several proposed accommodations to his employer. The Court of Appeals for the Eighth Circuit found two of the accommodations to be reasonable: "TWA would suffer no undue hardship if it were required to replace Hardison either with supervisory personnel or with qualified personnel from other departments. Alternatively, . . . TWA could have replaced Hardison on his Saturday shift with other available employees through the payment of premium wages." 35 Justice White, writing for the Court, reversed the Eighth Circuit and rejected the accommodations: "Both of these alternatives would involve costs to TWA, either in the form

so See TWA v. Hardison, 432 U.S. 63, 93 n.6 (1977) (Marshall, J., dissenting) ("As a matter of law, I seriously question whether simple English usage permits 'undue hardship' to be interpreted to mean 'more than de minimis cost' ....").

9I David L. Gregory, Religious Harassment in the Workplace: An Analysis of the EEOC's Proposed Guidelines, 56 MONT. L. REV. 119, 127 (1995) (arguing that Ansonia and Hardison have made Title VII "largely meaningless as a source of protection for the religiously observant employee of the secular employer"); see also I CHARLES A. SULLIVAN ET AL., EMPLOYMENT DISCRIMINATION \$ 9.3.3, at 391 (2d ed. 1988) ("In reading $\$ 701(j)$ so narrowly, the Supreme Court has clearly failed to fulfill the intent of Congress.").

In contrast, the Title VII requirement of religious accommodation does not extend to sectarian employers. Religious organizations may discriminate on the basis of religion for employment in connection with their religious activities. See Gregory, supra, at 127.

${ }^{32} 432$ U.S. 63 (1977).

${ }^{33}$ See id. at 84-85.

${ }^{34}$ See id. at 68 (describing the origins of Hardison's complaints). The "cost" of violating the collective bargaining agreement-liability under the National Labor Relations Act-is discussed infra Part I.B.

${ }^{35} \mathrm{Id}$. at 84 . The plaintiff's position as clerk in an airline-maintenance facility required staffing 24 hours per day, 365 days per year. As a result, it was necessary for another employee to work in Hardison's stead. See id. at 66-67. 
of lost efficiency in other jobs or higher wages. To require TWA to bear more than a de minimis cost in order to give Hardison Saturdays off is an undue hardship."36 Justice Marshall, in dissent, noted the trifling extent of the efficiency loss discussed by the Court: $\$ 150$ total in overtime costs until Hardison would have regained enough seniority to become "eligible to transfer back to his previous department." ${ }^{37}$

Subsequent courts have attempted to distinguish between the trivial costs that qualify as undue hardships, and the even more trivial costs that do not. In Protos v. Volkswagen of America, Inc., ${ }^{38}$ for example, the Third Circuit distinguished Hardison on its facts: "Volkswagen regularly maintained, along with employees assigned to specific posts on the assembly line, a crew of roving absentee relief operators (ARO) to be deployed as substitutes for absent employees." ${ }^{\text {"9 }}$ The Protos court accepted the district court's conclusions that the AROs were as efficient as Angeline Protos, and that "the employer here was not obliged to pay higher wages in order to fill Protos's vacancy." 40 Yet, the efficiency costs can be attenuated, and still represent an undue hardship. They can, for example, stem from

${ }^{36}$ Id. at 84; see also 3 LEX K. LARSON, EMPLOYMENT DISCRIMINATION § 56.03[1] (1995) (discussing the Hardison Court's focus on the cost to coemployees as a result of favoring religious employees).

${ }^{37}$ Hardison, 432 U.S. at 92 n.6. Justice Marshall was probably justified in noting the absurdity of the majority's definition. Although courts consider the loss of a day's pay to the religious employee "insubstantial," see Pinsker v. Joint District No. 28J, 735 F.2d 388, 391 (10th Cir. 1984) (holding that a school board's paid leave policy did not substantially burden a Jewish teacher's rights under either Title VII or the First Amendment when the policy required him to take occasional days of unpaid leave), under Hardison much smaller costs are found to unduly burden the employer, the party presumably better able to spread or absorb the cost.

33797 F.2d 129 (3d Cir.), cert. denied, 479 U.S. 972 (1986).

${ }^{39}$ Id. at 135.

${ }^{40}$ Id.; see also Brown v. General Motors Corp., 601 F.2d 956, 960 (8th Cir. 1979) (finding that "no monetary costs and de minimus [sic] efficiency problems were actually incurred during the three month period in which [the plaintiff] was accommodated," and rejecting the employer's suggestion to examine the "theoretical' future effects" and costs of other Sabbatarians subsequently seeking similar accommodation). 
"disruption of work routines, and a lowering of morale" among coworkers. ${ }^{41}$ The willingness to find an undue hardship is heightened in cases in which public safety may be compromised by such disruptions. ${ }^{42}$

Labor unions are held to a somewhat higher standard than the employers whose workers they represent; ${ }^{43}$ while most cases seem to indicate that any monetary expense by an employer amounts to undue hardship, even when those expenses are only a drop in the bucket of the employer's revenues, courts have routinely found that an employee's objection to union affiliation, and the consequential loss to the union of that employee's dues, cannot constitute undue hardship. ${ }^{44}$

${ }^{41}$ Brener v. Diagnostic Ctr. Hosp., 671 F.2d 141, 147 (5th Cir. 1982) ("Brener's characterization of complaints by others as mere grumbling underestimates the actual imposition on other employees in depriving them of their shift preference at least partly because they do not adhere to the same religion as Brener."); see also Wilson v. U.S. West Communications, 58 F.3d 1337, 1339 (8th Gir. 1995) (finding it unnecessary to reach an undue hardship analysis because the employer reasonably accommodated the plaintiff-employee whose insistence on wearing a graphic anti-abortion pin to work caused disturbances and a loss of efficiency among her coworkers).

${ }^{42}$ See Beadle v. City of Tampa, 42 F.3d 633, 637 (11th Cir.) ("When the employer's business involves the protection of lives and property, courts should go slow in restructuring [the business's] employment practices." (quotation omitted)), cert. denied, 115 S. Ct. 2600 (1995).

${ }^{43}$ Unions fall within the scope of Title VII. See 42 U.S.C. $\$ 2000 \mathrm{e}-2$ (c) (3) (1994) (stating that it is an unlawful employment practice for a labor organization "to cause or attempt to cause an employer to discriminate against an individual in violation of this section"); see also 3 LARSON, supra note 36, § 56.07[3] (discussing the rationales for unions to be subject to the "reasonable accommodation" requirement).

${ }^{44}$ See, e.g., Tooley v. Martin-Marietta Corp., 648 F.2d 1239, 1244 (9th Cir.) ("The Steelworkers have not established that the 'substituted charity' accommodation, as applied here, will deprive the union of monies necessary for its maintenance or operation."), cert. denied, 454 U.S. 1098 (1981); Nottelson v. Smith Steel Workers, D.A.L.U. 19806, 643 F.2d 445, 451 (7th Cir.) ("Because a religious objector under a charity-substitute accommodation bears the same financial burden as his co-workers, he is not . . . seeking something for nothing, and the diversion of his contribution to a charity rather than the Union does not of itself make the accommodation unfair or unreasonable as a matter of law."), cert. denied, 454 U.S. 1046 (1981); Burns v. Southern Pac. Transp. Co., 589 F.2d 403, 407 (9th Cir. 1978) ("In our view, the loss of dues [in the amount of $\$ 19$ per month] to the Union is de minimis, even if so necessary to its fiscal well-being that its equivalent would be collected from the Local's. 300 members at a rate of 2 cents each per month."), cert. denied, 439 U.S. 1072 (1979). But see Yott v. North Am. Rockwell Corp., 602 F.2d 904, 909 (9th Cir. 1979) ("Exemption [as opposed to paying the amount of union dues to charity] involves no payment at all, and the history at Rockwell indicates friction has resulted from 'freeriders' defined as those who pay neither union dues nor the equivalent thereof to a charity."), cert. denied, 445 U.S. 928 (1980). In contrast to Burns, Hardison involved a total cost of $\$ 150$, likely to be substantially less than the cost in Burns, and was spread through a much larger organization. See TWA v. Hardison, 432 U.S. 63, 92 n.6 (1977) 


\section{B. Breaking the Law: Statutory Compliance Causing Undue Hardship}

In contrast to an employer's defense that economic factors cause undue hardship, the employer may claim that accommo-dation would result in violation of a statute or regulation, with the consequences of that violation constituting undue hard-ship. Typically, as in Hardison, the employer invokes the sen-iority provisions of collective bargaining agreements, which are enforced by the federal labor laws, to prevent the accommodation of Sabbatarians. ${ }^{45}$ As the Court explained in Hardison:

[W] do not believe that the duty to accommodate requires TWA to take steps inconsistent with the otherwise valid agreement. Collective bargaining, aimed at effecting workable and enforceable agreements between management and labor, lies at the core of our national labor policy, and seniority provisions are universally included in these contracts. Without a clear and express indication from Congress, we cannot agree with Hardison and the EEOC that an agreed-upon seniority system must give way when necessary to accommodate religious observances. ${ }^{46}$

(Marshall, J., dissenting).

The Americans with Disabilities Act of 1990 ( $\mathrm{ADA}$ "), by comparison, expressly looks to the resources of the employer as a factor in calculating undue hardship. Factors used in determining undue hardship for accommodating a disabled employee include: "(i) the nature and cost of the accommodation needed under this chapter; (ii) the overall financial resources of the facility or facilities involved in the provision of the reasonable accommodation ....; (iii) the overall financial resources of the covered entity [as a whole rather than on a particular plant] . . ." 42 U.S.C. $\S 12111$ (10)(B) (i)-(iv) (1994).

${ }^{45}$ See, e.g., Hardison, 432 U.S. at 76-77; Lee v. ABE Freight Sys., Inc., 22 F.3d 1019, 1022 (10th Cir. 1994); Blair v. Graham Correctional Ctr., 4 F.3d 996, No. 92-1597, 1993 WL 331886, at *2 (7th Cir. Sept. 1, 1993) (unpublished table decision), cert. denied, 114 S. Ct. 924 (1994).

Title VI itself exempts neutral seniority provisions from its scope:

Notwithstanding any other provision of this subchapter, it shall not be an unlawful employment practice for an employer to apply different standards of compensation, or different terms, conditions, or privileges of employment pursuant to a bona fide seniority or merit system ... provided that such differences are not the result of an intention to discriminate....

42 U.S.C. $\S 2000 \mathrm{e}-2$ (h) (1994).

${ }^{46}$ Hardison, 432 U.S. at 79. For other Sabbatarian cases, see, e.g., ABF Freight Sys., 22 F.3d at 1023 ("Nor does Title VII require an employer to violate a valid labor agreement to accommodate an employee."); Mann v. Frank, 7 F.3d 1365, 1369 (8th Cir. 1993) ("Compelling [the coworker] Higgins to work involuntarily in Mann's place would have contravened the seniority and [overtime shift-assignment] provisions of the collective bargaining agreement and deprived Higgins of her contractual rights. This proposed accommodation constitutes undue hardship."); Blair, 1993 WL 331886, at **2 ("We are convinced that Graham's inability to accommodate Blair's scheduling 
Labor laws can interfere with an employee's exercise of religion in contexts other than Sabbatarianism. For example, in one case, an employee's religious beliefs prevented him from affiliating with the labor union, and, furthermore, prevented him from mak-ing a mandatory donation to charity-the collective bargaining agreement's alternative to paying dues for employees with relig-ious objections to union affiliation. ${ }^{47}$ The Ninth Circuit held: "[E]xemption [from paying union dues] ... requires such a substantial alteration in the relationship between the parties and significant erosion of the congressional purpose in permitting union security clauses that it goes beyond reasonable accommodation." $48 \quad$ G o ve $\mathrm{r} \mathrm{n} \mathrm{m} \mathrm{e} \mathrm{n} \mathrm{t}$ regulation outside the ambit of labor laws can also sometimes prevent an employer from accommodating the religious needs of its employees. Examples of this interference may include laws and regulations concerning drug use, ${ }^{49}$ garb $^{50}$ and grooming. ${ }^{51}$

\section{RFRA: COMPELIING INTERESTS TRUMPING UNDUE HARDSHIPS}

\section{A. An Overview of RFRA}

In 1993 Congress passed with near-unanimity, ${ }^{52}$ and President Clinton signed into law, ${ }^{53}$ the Religious Freedom Restoration Act

request was ... [caused] by the constraints placed upon Graham by the collective bargaining agreement and the demands of managing the security force . . ..").

${ }_{47}$ See Yott, 602 F.2d at 906-07. Offering the alternative of a donation to charity will presumptively make the accommodation reasonable, over the objection of the employer or the union. See McDaniel v. Essex Int'l, Inc., 696 F.2d 34, 38 (6th Cir. 1982) (finding that the union violated Title VII when it refused to address McDaniel's proposal of a substitute donation to charity).

${ }^{48}$ Yott, 602 F.2d at 909.

49 See, e.g., Toledo v. Nobel-Sysco, Inc., 892 F.2d 1481, 1491-92 (10th Cir. 1989) (finding that the employer's compliance with Department of Transportation regulations regarding drug use by truck drivers made it unreasonable to accommodate the needs of a religious peyote smoker), cert. denied, 495 U.S. 940 (1990).

${ }_{50}$ See, e.g., United States v. Board of Educ., 911 F.2d 882, 891 (3d Cir. 1990) (finding that the employer-school district's compliance with the Pennsylvania Garb Statute, which prohibits public-school teachers from wearing religious attire in the classroom, was necessary to avoid exposure to criminal liability).

${ }^{51}$ See, e.g., Bhatia v. Chevron U.S.A., Inc., 734 F.2d 1382, 1383 (9th Gir. 1984) (employer's compliance with standards promulgated by California's Occupational Safety and Health Administration made it unreasonable to accommodate a man who could not shave his beard for religious reasons).

${ }^{52}$ On October 27, 1993, the bill passed the Senate by a vote of 97-3. See 139 CoNG. REC. S14,470 (daily ed. Oct. 27, 1993). On November 3, 1993, the House passed the Senate version. See 139 CoNG. REC. H8715 (daily ed. Nov. 3 1993).

${ }^{53}$ See 139 CONG. REC. D1315 (daily ed. Nov. 16, 1993). 
of 1993 ("RFRA"). ${ }^{54}$ The Act responded to the Supreme Court's decision in Employment Division v. Smith, ${ }^{55}$ a case in which the State of Oregon denied unemployment benefits to the plaintiff, a member of the Native American Church, because sacramental use of the drug peyote $^{56}$ was deemed by the State to constitute "work-related 'misconduct.""57 The Court, per Justice Scalia, applied a new First Amendment test to Oregon's controlled substance law when it examined the plaintiff's Free Exercise complaint. ${ }^{58}$ The Court held that "generally applicable, religion-neutral laws that have the effect of burdening a particular religious practice need not be justified by a compelling governmental interest." ${ }^{\text {} 9}$ Therefore, religion-neutral laws need only surmount the rationality test to be affirmed. The Court justified its decision by analyzing the haphazard application of the compelling-interest test, ${ }^{60}$ and by considering the practical ramifications of truly utilizing a compelling interest test ${ }^{61}$-namely,

5442 U.S.C. $\$ 2000 \mathrm{bb}$ to $\mathrm{bb}-4$ (1994).

35494 U.S. 872 (1990).

${ }^{56}$ Native American Church members "believe, and their sincerity has never been at issue, that the peyote plant embodies their deity, and eating it is an act of worship and communion. Without peyote, they could not enact the essential ritual of their religion." Id. at 919 (Blackmun, J., dissenting).

${ }^{57} \mathrm{Id}$. at 874.

${ }^{58}$ Smith has been attacked as an effort of judicial overreaching-an instance where the Court need not have addressed the criminality of ritualistic peyote use, since the Oregon Supreme Court found the issue irrelevant as a matter of state unemployment compensation law. See Michael W. McConnell, Free Exercise Revisionism and the Smith Decision, 57 U. CHI. L. REV. 1109, 1114 (1990) ("The most important decision interpreting the Free Exercise Clause in recent history, then, was rendered in a case in which the question presented was entirely hypothetical, irrelevant to the disposition of the case as a matter of state law, and neither briefed nor argued by the parties.").

${ }^{59}$ Smith, 494 U.S. at 886 n.3. The Court has, however, retained a strict-scrutiny analysis for laws not both religion-neutral and of general applicability. See Church of the Lukumi Babalu Aye, Inc. v. City of Hialeah, 113 S. Ct. 2217, 2233-34 (1993) (requiring a compelling municipal interest for, and applying a least-restrictive-means analysis to, an ordinance with the purpose of banning religious animal sacrifice).

${ }^{60}$ See Smith, 494 U.S. at 881 ("The only decisions in which we have held that the First Amendment bars application of a neutral, generally applicable law to religiously motivated action have involved not the Free Exercise Clause alone, but the Free Exercise Clause in conjunction with other constitutional protections ...."). This revisionistic examination of Free Exercise precedents, however, has been routinely challenged in the academy. See, e.g., McConnell, supra note 58, at 1120, 1125 (describing the Court's use of precedent as "troubling, bordering on the shocking" and stating that "the primary and affirmative precedent marshalled by the Court to support its decision consists entirely of overruled and minority positions."); Steven D. Smith, The Rise and Fall of Religious Freedom in Constitutional Discourse, 140 U. PA. L. REV. 149, 234 (1991) ("As an exhibition of legal analysis, Justice Scalia's majority opinion in Smith is an intellectual disaster.").

${ }^{61}$ See McConnell, supra note 58, at 1127 (“[T] he Supreme Court before Smith did 
the lawlessness that might result from carving exceptions from many laws. ${ }^{62}$

In response to the national uproar generated by Smith, Congress enacted RFRA and restored the compelling-interest test to neutral laws of general applicability, ${ }^{63}$ observing that such a test is "workable ... for striking sensible balances between religious liberty and competing prior governmental interests. ${ }^{\text {"64 }}$ RFRA represented a triumph of accommodationism-an interpretation of the Religion

not really apply a genuine 'compelling interest' test.").

${ }^{62}$ See Smith, 494 U.S. at 885 ("To make an individual's obligation to obey such a law contingent upon the law's coincidence with his religious beliefs, except where the State's interest is 'compelling'-permitting him, by virtue of his beliefs, 'to become a law unto himself,' . . . contradicts both constitutional tradition and common sense." (citation omitted)). But see McConnell, supra note 58, at 1151 ("That the idea may be anarchic does not mean we should dismiss it, for there is reason to believe that this inalienable rights understanding [of freedom of conscience, protected by accommodations authorized by the First Amendment] is the genuine theory of the Religion Clauses of the First Amendment.").

${ }^{63}$ The constitutionality of RFRA, so far as it usurps the Court's role as final interpreter of the Constitution, has been hotly debated both in the academic community, compare, e.g., Christopher L. Eisgruber \& Lawrence G. Sager, Why the Religious Freedom Restoration Act Is Unconstitutional 69 N.Y.U. L. REV. 437 (1994) with Bonnie I. Robin-Vergeer, Disposing of the Red Herrings: A Defense of the Religious Freedom Restoration Act, 69 S. CAL. L. REV. 589 (1996) (defending the constitutionality of RFRA), and in the courts, compare, e.g., Flores v. City of Boerne, 73 F.3d 1352 (5th Cir. 1996) (finding RFRA constitutional) with Hamilton v. Schriro, 74 F.3d 1545, 1557 (8th Cir. 1996) (McMillian, J., dissenting) (finding RFRA unconstitutional). While most courts have been able to dodge the issue of RFRA's constitutionality, see, e.g., Young v. Crystal Evangelical Free Church, 82 F.3d 1407, 1417 (8th Cir. 1996); Thiry v. Carlson, 78 F.3d 1491, 1495 n.l (10th Cir. 1996); Fawaad v. Jones, 81 F.3d 1084, 1087 n.3 (11th Cir. 1996), those circuits that have spent significant time addressing the issue have found the statute to be a legitimate exercise of congressional expansion of constitutional rights. See Sasnett v. Sullivan, 91 F.3d 1018, 1021-22 (7th Cir. 1996); EEOC v. Catholic Univ. of Am., 83 F.3d 455, $469-71$ (D.C. Cir. 1996); Flores, 73 F.3d at 1364. For the purposes of this Comment, RFRA is presumed to be constitutional.

${ }^{64} 42$ U.S.C. $\$ 2000 \mathrm{bb}(\mathrm{a})(5)(1994)$. 
Clauses that requires, or at least encourages, the Government to accommodate individuals' religious beliefs and exercise. ${ }^{65}$

RFRA creates a federal claim for "persons whose religious exercise is substantially burdened by government." ${ }^{\text {}} 6$ The language in RFRA could not be clearer:

(a) ...

Government shall not substantially burden a person's exercise of religion even if the burden results from a rule of general applicability, except as provided in subsection (b) of this section.

(b) ...

Government may substantially burden a person's exercise of religion only if it demonstrates that application of the burden to the person-

(1) is in furtherance of a compelling governmental interest; and

(2) is the least restrictive means of furthering that compelling governmental interest. ${ }^{67}$

RFRA, then, requires the courts to apply the compelling-interest test in all instances-even though such a test was not always adopted, or adopted rigorously, in pre-Smith case law. ${ }^{68}$ Instead, RFRA adopts the position of those cases that rigorously applied the compellinginterest test. ${ }^{69}$

${ }^{65}$ See Arlin M. Adams \& Sarah B. Gordon, The Doctrine of Accommodation in the Jurisprudence of the Religion Clauses, 37 DEPAUL L. REV. 317, 318-19 (1988) (arguing that accommodation is an "allowable governmental deference to the religious requirements of a pluralistic society"); see also McConnell, supra note 58, at 1111 (stating that RFRA was the result of a drive for a legislative correction of the Smith decision led by a "broad-based coalition of religious and civil liberties groups . . . and over a hundred constitutional law scholars"); Laura S. Underkuffler, Discrimination' on the Basis of Religion: An Examination of Attempted Value Neutrality in Employment, 30 WM. \& MARY L. REV. 581, 625 (1989) ("Laws prohibiting religious discrimination in employment must be interpreted in a manner that recognizes the legitimacy of religious values and practice, and that targets the valid purpose of those laws: the eradication of barriers to equal employment opportunity due to religious status discrimination.").

${ }_{66}^{6} 42$ U.S.C. $\$ 2000 \mathrm{bb}$ (b) (2) (1994); see also 42 U.S.C. \$ $2000 \mathrm{bb}-1$ (c) (1994) (“A person whose religious exercise has been burdened in violation of this section may assert that violation as a claim or defense in a judicial proceeding and obtain appropriate relief against a government.").

6742 U.S.C. $\S 2000 \mathrm{bb}-1$ (a) to 1 (b) (1994).

as See supra note 61 .

${ }^{69}$ See 42 U.S.C. $\$ 2000 \mathrm{bb}(\mathrm{b})$ (1) (expressly naming Sherbert v. Verner, 374 U.S. 398 (1963), and Wisconsin v. Yoder, 406 U.S. 205 (1972)-two cases that adopted a stringent compelling-interest test-as precedent to follow). 


\section{B. RFRA and Employment Discrimination}

At first glance, RFRA would appear to extend to the acts of the federal and state Governments as employers, since the Government may not substantially burden religious exercise without a compelling interest; the statute does not distinguish legislative acts from employment actions of public sector employers. ${ }^{70}$ Under this reading, RFRA would replace the undue hardship test with the much tougher compelling-interest test-making religious accommodations prevalent in the public sector. ${ }^{71}$ But Congress did not intend to affect Title VII, as the Senate Report states: "Nothing in this act shall be construed as affecting religious accommodation under Title VII of the Civil Rights Act of 1964." ${ }^{\text {"72 }}$ As a result, if one is to pay respect to the legislative history, RFRA has no direct effect on religious accommodations in the workplace. $^{73}$

Rather than replacing the undue hardship test of Title VII with the compelling-interest test, RFRA has a more subtle effect on the workplace. As discussed above, employers may claim undue hardship (or the equivalent, a lack of any reasonable

${ }^{70}$ Congress enacted RFRA under its "authority to provide statutory protection for a constitutional value when the Supreme Court has been unwilling to assert its authority." H.R. REP. NO. 88, 103d Cong., 1st Sess. 9 (1993). This authority is Article I, Section Eight of the Constitution with respect to federal legislation, and Section Five of the Fourteenth Amendment with respect to state legislation. See id. Accordingly, since the state-action requirement remains, RFRA would not replace the undue hardship test with one of compelling interest for private employers.

Title VII, however, reaches private employers because it is grounded in the Commerce Clause. See 42 U.S.C. \$2000e(g) (1994) (defining "commerce" as interstate commerce for the purpose of Title VII). As a result, those employers who do not participate in interstate commerce-presumed to be those employers with fewer than 15 employees-fall outside the ambit of Title VII. See 1 SULLIVAN ET AL., supra note $31, \S 1.3$ (discussing the statutory definition of employer under Title VII).

${ }^{71}$ A textualist might find, therefore, that RFRA replaces the de minimis-undue hardship standard for public employers with a standard that requires a compelling interest-economic or non-economic-before a public employer would be justified in failing to accommodate the religious employee.

72 S. REP. NO. 111, supra note 22 , at 13.

${ }^{73}$ At least one court, however, has ignored the legislative history and has found that RFRA does apply directly to Title VII. See EEOC v. Catholic Univ. of Am., 83 F.3d 455, 468 (D.C. Cir. 1996) (finding that RFRA "has, in effect, incorporated a statutory 'compelling interest' test into Title VII"). Although such an interpretation has uncertain effects for public employers, see supra note 70 and accompanying text, since RFRA still requires state action, it does not directly modify the Title VII test with respect to the duties of private employers to accommodate. Therefore, even if the legislative history is ignored, the analysis for private employers' duties is the same as that presented in the text. 
methods of accommodation) in two manners. First, the employer may claim that accommodation poses a greater-than-de-minimis economic burden. If RFRA does not directly affect Title VII, then this standard is not changed, either for public or private employers.

But, as discussed above in Part I.B, in Title VII suits employers typically use compliance with federal or state laws and regulations as a shield. If the employer invokes this defense and argues that it would face civil or criminal liability for accommodating the employee, then an undue hardship undoubtedly exists. ${ }^{74}$ Historically, those statutes relied upon by employees have presumptively-without discussion-been considered valid; Title VII does not chip away at other laws. RFRA upsets this balance. In short, it is the "clear and express indication from Congress" that the Hardison Court sought. ${ }^{75}$

RFRA creates a new cause of action: one which, after the employee shows substantial interference with her right of free exercise, places the burden on the employer, union, or intervenorGovernment to demonstrate that the legislation is narrowly tailored to further a compelling state interest. ${ }^{76}$

In employment-discrimination cases, the typical scenario under RFRA is as follows. The employee sues her employer under Title VII. First, the employee shows that employment requirements imposed a substantial burden on her bona fide religious beliefs. ${ }^{77}$ Such a demonstration satisfies the employee's prima facie burdens under both Title VII and RFRA; the ordinary Sabbatarian, for example, can easily meet these requirements. ${ }^{78}$ If the employer can defend itself with an economic rationale-by showing that accommodation would require the payment of overtime or the hiring of another worker-

${ }^{74}$ See United States v. Board of Educ., 911 F.2d 882, 891 (3d Cir. 1990) ("[W]e think it follows a fortiori that it would be an undue hardship to require [an employer] to violate an apparently valid criminal statute.").

75 TWA v. Hardison, 432 U.S. 63,79 (1977). While RFRA does not directly state that "seniority system[s] must give way when necessary to accommodate religious observances, ${ }^{n} i d$. at 79 , it does state, more generally, that all Government interference must give way.

${ }_{76}$ See, e.g., Werner v. McCotter, 49 F.3d 1476, 1480 (10th Cir. 1995) (discussing the shifting burdens of RFRA), cert. denied, 115 S. Ct. 2625 (1995).

77 Cf. Underkuffler, supra note 65, at 616 (arguing for a system in which "[t]he issue ... should be whether the employee's employment opportunities are curtailed because of his or her religious affiliation or identity").

${ }^{78}$ See Hardison, 432 U.S. at 71-76 (recognizing that reasonable accommodation is required under Title VII when a bona fide belief clashes with employment requirements); Sherbert v. Verner, 374 U.S. 398, 406 (1963) (finding that Sabbatarianism triggers the compelling interest requirement under the First Amendment). 
then, as stated above, RFRA does not apply. Should the employer, however, defend its failure to accommodate on the basis of compliance with a statute or regulation-if, for example, the employer claims that but for compliance with the federal labor laws, accommodation would not pose an undue hardship-RFRA enters the scene. And RFRA mandates that the Government may not substantially burden the employee's free exercise rights without a compelling interest. ${ }^{79}$ Following the employer's claim of reliance on statutory compliance, the district court may allow the Government to intervene to defend the validity of the statute relied on by the employer. ${ }^{80} \mathrm{At}$ this point, the party defending the application of the statute-the employer or the Government, should it intervene-has the burden under RFRA of showing that the statute or regulation in question is the least restrictive means of furthering a compelling Government interest. While RFRA does not modify the Title VII burdens, employment discrimination actions provide a forum at which the Government's interference with religious exercise can be questioned.

\section{G. Reconciling Pre-RFRA Free Exercise Case Law}

Although RFRA creates a statutory rather than constitutional cause of action, RFRA seeks to achieve the same results that certain pre-Smith Free Exercise cases reached. Those cases support the interwoven relationship between Title VII and RFRA for which this Comment argues. RFRA's express purpose is to restore Sherbert $v$. Verner $^{81}$ to law, $^{82}$ and Sherbert, like the instant discussion, involved

${ }^{79} \mathrm{Cf}$. Underkuffler, supra note 65 , at 614 (positing that "[in] cases . . in which a nonreligious work environment . . . conflict[s] with an employee's religious requirements [the employee may assert] a claim of religious discrimination under a statute that mandates an employer's accommodation of an employee's religious beliefs or practices").

${ }^{80}$ The Federal Rules of Civil Procedure permit such intervention:

When a party to an action relies for ground of claim or defense upon any statute or executive order administered by a federal or state governmental officer or agency or upon any regulation, order, requirement or agreement issued or made pursuant to the statute or executive order, the officer or agency upon timely application may be permitted to intervene in the action.

FED. R. CIV. P. 24(b) (2).

${ }^{81} 374$ U.S. 398 (1963).

${ }^{82}$ See 42 U.S.C. $\$ 2000 \mathrm{bb}(\mathrm{b})$ (1) (1994). The statute also cites Wisconsin v. Yoder, 406 U.S. 205 (1972). In that case, the Court applied strict scrutiny to exempt the Amish from mandatory formal education beyond the eighth grade. See id. at 215 ("[O]nly those interests of the highest order and those not otherwise served can overbalance legitimate claims to the free exercise of religion."). 
employment law. In Sherbert, a Seventh-Day Adventist was "discharged by her South Carolina employer because she would not work on Saturday, the Sabbath Day of her faith." ${ }^{83}$ South Carolina denied the employee unemployment benefits because she was not "able to work" and "available to work" as needed on Saturdays. ${ }^{84}$ The Court found that even if a compelling interest existed, the statute was unconstitutional: "For even if the possibility of spurious claims did threaten to dilute the fund and disrupt the scheduling of work, it would plainly be incumbent upon the appellee[] [state administrators] to demonstrate that no alternative forms of regulation would combat such abuses without infringing First Amendment rights." 85

Perhaps more important to Title VII cases than the actual holding of Sherbert was the Court's justification for reaching its holding. The Court noted that the state law did not directly violate the employee's free exercise rights; instead, the violation only occurred because the employee would become compelled to work on her Sabbath as a result of the unavailability of benefits:

In a sense the consequences of such a disqualification to religious principles and practices may be only an indirect result of welfare legislation within the State's general competence to enact; it is true that no criminal sanctions directly compel appellant to work a sixday week. But this is only the beginning, not the end, of our inquiry. ${ }^{86}$

In Title VII cases, the substantial burden on the employee's free exercise is also only an indirect result of welfare legislation within the Government's general competence to enact. But, under Sherbert, this indirectness does not bar the employee from relief under her RFRA claim.

${ }^{8 s}$ Sherbert, 374 U.S. at 399.

${ }^{84} I d$, at 400 (quoting the South Carolina Unemployment Compensation Act).

${ }^{85}$ Id. at 407 . Sherbert cannot be seen as a mere anomaly. The Court addressed the interplay between unemployment benefits and free exercise three times after Sherbert and each time struck down the unemployment-benefit statute. In Thomas v. Review Bd., 450 U.S. 707 (1981), the Court, per Chief Justice Burger, examined the denial of unemployment benefits to a Jehovah's Witness who terminated his job because "his religious beliefs forbade participation in the production of armaments." Id. at 709. The Court applied the same test as in Sherbert. "The state may justify an inroad on religious liberty by showing that it is the least restrictive means of achieving some compelling state interest." Id. at 718; see also Frazee v. Illinois Dep't of Employment Sec., 489 U.S. 829, 835 (1989) (reasserting the application of strict scrutiny review of denials of unemployment benefits in a case factually similar to Sherbert); Hobbie v. Unemployment Appeals Comm'n, 480 U.S. 136, 141 (1987) (same).

${ }^{86}$ Sherbert, 374 U.S. at 403-04. 
Those pre-Smith cases at odds with Sherbert can be distinguished from the circumstances currently arising in the Title VII context. ${ }^{87}$ Some Free Exercise cases are limited to military ${ }^{88}$ or penological ${ }^{89}$ contexts. In other cases, the Court was reluctant to require accommodation without explicit congressional guidance for fear that such accommodation would handcuff the legislature in its efforts to achieve its desired goals. In Braunfeld v. Brown, ${ }^{90}$ for example, the Court upheld Pennsylvania's Sunday closing law as applied to Orthodox Jewish retailers who claimed they would be forced out of business by continued enforcement of the law. ${ }^{91}$ In applying rational basis review, the Court, anomalously, seemed to require strict scrutiny to strike down the law:

To strike down, without the most critical scrutiny, legislation which imposes only an indirect burden on the exercise of religion ... would radically restrict the operating latitude of the legislature. . . . [I] t cannot be expected, much less required, that legislators enact no law regulating conduct that may in some way result in an economic disadvantage to some religious sects and not to others because of the special practices of the various religions. ${ }^{92}$

${ }^{87}$ While RFRA is meant to "guarantee [the] application [of the compellinginterest test] in all cases where free exercise is substantially burdened," 42 U.S.C. $\S 2000 \mathrm{bb}(\mathrm{b})(1)$, the analysis in the text accompanying this footnote is meant to distinguish cases where, if the compelling-interest test was applied (and it is not clear that it was), it was not applied faithfully.

${ }^{88}$ See Goldman v. Weinberger, 475 U.S. 503, 507 (1986) ("Our review of military regulations challenged on First Amendment grounds is far more deferential than constitutional review of similar laws or regulations designed for civilian society."). In 1986, Congress responded to the Goldman decision by overturning it. See 10 U.S.C. $\$ 774$ (1994) (declaring, subject to certain exceptions, that "a member of the armed forces may wear an item of religious apparel while wearing the uniform of the member's armed force"). RFRA applies as equally to military claims as to other claims. See S. REP. No. 111, supra note 22, at 12 ("Under the unitary standard set forth in the act, courts will review the free exercise claims of military personnel under the compelling governmental interest test.").

${ }^{89}$ See O'Lone v. Estate of Shabazz, 482 U.S. 342, 349-50 (1987) (disregarding the Third Circuit opinion that placed the burden on the state to show that security risks would be implicated if the prisoners' religious rights were accommodated, and applying the far more deferential rational relationship test where the penological interest of security is implicated). RFRA, however, appears to restore the Third Circuit's test in Shabazz. See Jolly v. Coughlin, 76 F.3d 468, 475 (2d Cir. 1996) ("[T] he legislative history of RFRA makes clear that the compelling interest test is to apply to free exercise claims by prison inmates."); S. REP. NO. 111, supra note 22, at 11 ("The act would return to a standard that was employed without hardship to the prisons in several circuits prior to the O'Lone decision.").

${ }^{90} 366$ U.S. 599 (1961).

${ }^{91}$ See id. at 605.

${ }^{92}$ Id. at 606; see also United States v. Lee, 455 U.S. 252, 261 (1982) ("The tax 
This concern is irrelevant under RFRA, however, since RFRAoverruling the similar concerns articulated in Smith-is meant to restrict the legislature's operating latitude. ${ }^{93}$

Other cases can be distinguished by virtue of the extent of interference with free exercise caused by the Government. ${ }^{94}$ In United States v. Lee, ${ }^{95}$ the Court upheld application of the Social Security tax to Amish employers of other Amish, even after accepting the contention that the tax violated Amish beliefs. ${ }^{96}$ It is not clear that such an interference would rise to the level of a "substantial burden" as required by RFRA. In the same vein, it is uncertain whether free exercise is substantially burdened by the racial integration of a religious organization, ${ }^{97}$ by the government's use of a Social Security number, ${ }^{98}$ or by timber-harvesting and roadbuilding near (but not on) Native American tribes' sites of worship. ${ }^{99}$ In contrast, Title VII cases present a clear conflict: a "cruel choice" for the employee between religion and employment. ${ }^{100}$ In

imposed on employers to support the social security system must be uniformly applicable to all, except as Congress provides explicitly otherwise.").

${ }_{93}$ The Court in Sherbert distinguished Braunfeld on different grounds, finding that a day of leisure could be a compelling interest, and that exemptions might undermine that interest. See Sherbert v. Verner, 374 U.S. 398, 408-09 (1963).

${ }^{94}$ The examination of the centrality of a religious belief is admittedly a difficult undertaking, and more so for the Government than for the author. Nonetheless, this analysis is necessary because of the "substantial burden" requirement of RFRA, and because it demonstrates that application of RFRA to Title VII cases is particularly important. Furthermore, this undertaking has been sanctioned by the Court. See Bowen v. Roy, 476 U.S. 693, 706 (1986) (distinguishing incidental burdens from those where "governmental action or legislation ... compels conduct that some find objectionable for religious reasons").

${ }^{95} 455$ U.S. 252 (1982).

96 The Court explained:

The Amish believe that there is a religiously based obligation to provide for their fellow members the kind of assistance contemplated by the social security system. . . . Because the payment of the taxes or receipt of benefits violates Amish religious beliefs, compulsory participation in the social security system interferes with their free exercise rights.

Id. at 257.

97 See Bob Jones Univ. v. United States, 461 U.S. 574, 603-04 (1983) ("Denial of tax benefits will inevitably have a substantial impact on the operation of private religious schools, but will not prevent those schools from observing their religious tenets.").

${ }^{98}$ See Bowen v. Ray, 476 U.S. 693, 700-01 (finding no interference with a child's "freedom to believe, express, and exercise' his religion") (citations omitted).

${ }^{99}$ See Lyng v. Northwest Indian Cemetery Protective Ass'n, 485 U.S. 439, 449 (1988) ("[T] $[$ he affected individuals [would not] be coerced by the Government's action into violating their religious beliefs . ... .").

${ }^{100}$ Braunfeld v. Brown, 366 U.S. 599, 616 (1961) (Stewart, J., dissenting) ("Pennsylvania has passed a law which compels an Orthodox Jew to choose between 
Title VII cases, government legislation would compel conduct the employee finds objectionable on religious grounds. ${ }^{101}$

The combination of a free-exercise claim with a Title VII claim had seldom been attempted before RFRA. ${ }^{102}$ In United States $v$. Board of Education, ${ }^{103}$ a Muslim schoolteacher sued the Philadelphia School Board under Title VII for firing her for wearing to school, pursuant to her religious beliefs, a head scarf and long loose dress. ${ }^{104}$ Because the School Board defended its decision on its compliance with Pennsylvania's Garb Statute, the teacher challenged the Garb Statute on a Free Exercise Clause basis. ${ }^{105}$ As against the School Board, the court found:

From the inception of this case, the School Board has insisted that it had no choice but to comply with the Garb Statute. . . . For the Board to have accommodated Ms. Reardon, it would have been required to expose its administrators to a substantial risk of criminal prosecution, fines, and expulsion from the profession. This, the Board insists, would have been an undue hardship on it .... We agree. $^{106}$

Having found that the School Board was entitled to comply with a valid criminal law, the court examined the Free Exercise grounds and found that the statute "advance[d] a compelling interest in maintaining the appearance of religious neutrality in the public school classroom." ${ }^{107}$ Since the Garb Statute was targeted at

his religious faith and his economic survival. That is a cruel choice. It is a choice which I think no State can constitutionally demand.").

${ }^{101}$ See Lyng, 485 U.S. at 449; Bowen, 476 U.S. at 706.

${ }^{102}$ In a broader context, one commentator has explained:

Despite the visibility of the First Amendment guarantee of free exercise of religion and its prohibition against establishment of religion by the government, in employment cases it is invoked with far less frequency than Title VII as a direct source of legal protection. There are two reasons for this. First, the First Amendment does not generally restrict private employers[, and s] econd, Title VII['s] ... depth and comprehensiveness ... may make a purely constitutional claim unappealing by comparison.

3 LARSON, supra note $36, \$ 55.08$ (citation omitted).

${ }^{103} 911$ F.2d 882 (3d Cir. 1990).

${ }^{104}$ See id. at 884. Technically, the Department of Justice brought suit on behalf of the teacher. See id. at 885 . Title VII requires referral of an employee's complaint from the EEOC to the Attorney General when instituting suit against government entities. See 42 U.S.C. § 2000e-5(f)(1) (1994).

${ }^{105}$ See Board of Educ., 911 F.2d at 884 .

${ }^{106} \mathrm{Id}$. at 890.

${ }^{107}$ Id. at 889. Clearly, the State could not be forced to violate the Establishment Clause by accommodating the employee. Instead, the Third Circuit found that the State's interest in preserving an atmosphere of religious neutrality in the classroom could be compelling, even without a showing that such accommodation would violate 
eliminating the appearance of religion in classrooms, accommodation would have eviscerated the statute.

Unlike the Garb Statute, nearly all legislation challenged under Title VII is face-neutral toward religion. ${ }^{108}$ Accordingly, accommodation will not directly conflict with the legislative purposes embodied in the legislation. Instead, the party defending the validity of the statute-the employer or the intervenor Government-would be required to show that accommodations would compromise the nonreligious purpose of the statute; if unable to do so, the statute would not be the least restrictive means of accomplishing the legislative purpose.

\section{ChallengING THE "BURDENSOME" STATUTE: SENIORITY PROVISIONS OF COLLECTIVE BARGAINING AGREEMENTS}

TWA v. Hardison, itself, dealt with seniority provisions of collective bargaining agreements. "In the unionized workplace, seniority is purely a contractual concept, created and defined by the collective bargaining agreement." 109 Over ninety percent of collective bargaining agreements contain seniority provisions. ${ }^{110}$ These provisions prevent junior-level employees from being transferred to jobs or schedules which conflict with their religious practices. Because " $[\mathrm{u}]$ nions prize seniority provisions above almost any other part of the collective bargaining agreement,"111 an employer who

the Establishment Clause. See id. at 889 n.5.

${ }^{103}$ The vitality of the compelling-interest test for non-face-neutral legislation has never been in doubt. See Church of Lukumi Babalu Aye, Inc. v. City of Hialeah, 113 S. Ct. 2217, 2227 (1993) (noting that non-neutral legislation "is invalid unless it is justified by a compelling interest and is narrowly tailored to advance that interest"). Such legislation is rare as a result. The typical laws which conflict with an employee's free exercise, as I have suggested, are face-neutral, however, and include labor and public-safety laws.

${ }^{109}$ LAURA J. COOPER \& DENNIS R. NOLAN, LABOR ARBITRATION: A COURSEBOOK 163 (1994). The collective bargaining agreement, while contractual in nature, is "enmeshed in a framework of regulatory laws-in part state law but always against the background of federal labor legislation." ROBERT A. GORMAN, BASIC TEXT ON LABOR LAW: UNIONIZATION AND COLLECTIVE BARGAINING 541 (1976). The background of federal labor legislation of which Professor Gorman writes is largely federal common law. In Textile Workers Union of Am. v. Lincoln Mills of Ala., 353 U.S. 448, the Supreme Court found that section 301 (a) of the Labor Management Relations Act "authorizes federal courts to fashion a body of federal law for the enforcement of these collective bargaining agreements." Id. at 451.

${ }^{110}$ See COOPER \& NOLAN, supra note 109, 109, at 162.

${ }^{111}$ Id.; see also Firefighters Local Union No. 1784 v. Stotts, 467 U.S. 561,570 n.4 (1984) ("Seniority has traditionally been, and continues to be, a matter of great concern to American workers."). 
would like to accommodate a Sabbatarian, for example, will often not get the union's permission. ${ }^{112}$

Because RFRA creates an independent cause of action, rather than one derived from Title VII, it does not suffer from the same infirmity as did the plaintiff's claim in Hardison, namely Title VII's allowance of seniority provisions absent proof of discriminatory intent. ${ }^{113}$ The instant requirement is derived from section 703(h) of Title VII, which states that neutral seniority provisions are not an "unlawful employment practice." The RFRA claimant does not argue that the collective bargaining contract violates Title VII, but that the employer's invocation of federal labor law violates the statutory protections of RFRA. ${ }^{115}$ Title VII remains unchanged, but RFRA affects those other laws-including the federal common law that enforces collective bargaining agreements ${ }^{116}$ - directed to the workplace.

Accommodation from the seniority provisions does not undermine the government's compelling interest in regulating the relationship between employers and organized labor. The harm to the union will usually be temporary-in Hardison, the employee would have achieved the necessary seniority in a matter of months to avoid having to work on his Sabbath. ${ }^{117}$ Furthermore, the harm to the union caused by occasional scheduling adjustments would not burden the union any more than the union's loss of dues from any one member. ${ }^{118}$ Accommodating the religious employee would not

112 See, e.g., TWA v. Hardison, 432 U.S. 63, 63 (1977).

${ }^{113}$ See, e.g., Lorance v. AT\&T Technologies, Inc., 490 U.S. 900, 908 (1989) ("[O]ur cases ... treat the proof of discriminatory intent as a necessary element of Title VII actions challenging seniority systems.").

11442 U.S.C. $\$ 2000 \mathrm{e}-2(\mathrm{~h})$ (1994); see also, e.g., Lorance, 490 U.S. at 908 (explaining the Court's interpretation of $\S 703(\mathrm{~h}))$.

${ }^{115}$ While it might seem unusual to override Title VII's presumption of legality, the result is mandated by RFRA. The cause of action under RFRA, though factually intertwined with the Title VII complaint, is legally distinct. Under RFRA, the employee may directly attack the validity of the labor law. Title VII's statement that neutral bargaining agreements are permissible cannot abrogate the requirement in an employee's separate RFRA claim that such agreements be the least restrictive means of satisfying a compelling government interest.

${ }^{116}$ See supra note 109.

${ }^{117}$ Permanent situations, though, might create greater-than-de-minimis economic costs. These economic costs, however, are outside of RFRA and the Free Exercise Clause because of the lack of state action. See supra note 70 and accompanying text.

${ }^{118}$ See, e.g., Tooley v. Martin-Marietta Corp., 648 F.2d 1239, 1244 (9th Cir.) ("The Steelworkers have not established that the 'substituted charity' accommodation, as applied here, will deprive the union of monies necessary for its maintenance or operation."), cert. denied, 454 U.S. 1098 (1981); Nottelson v. Smith Steel Workers, 643 
appear to compromise the effectiveness of the union as a bargaining unit-hence it would not undermine the purposes of federal labor laws. It would violate RFRA, then, for the government to throw its weight behind the union and declare the employer's accommodation an unfair labor practice. Although it is true that this regime prefers the religious reasons for shift changes to the non-religious, ${ }^{119}$ RFRA embodies Congress's accommodationist interpretation of the Free Exercise Clause. Such an interpretation by nature favors religious reasons, and in this instance does not amount to a violation of the Establishment Clause. ${ }^{120}$

\section{CONCLUSION}

The implications of RFRA extend to every aspect of government regulation that burdens religion. In enacting RFRA, Congress has sent a mandate that none of its laws, nor the laws of the States, may substantially burden free exercise. It is only appropriate then, that RFRA, a statute meant to effectively overturn Supreme Court

F.2d 445, 451 (7th Cir.) ("Because a religious objector under a charity-substitute accommodation bears the same financial burden as his coworkers, he is not ... seeking something for nothing, and the diversion of his contribution to a charity rather than the Union does not of itself make the accommodation unfair or unreasonable as a matter of law."), cert. denied, 454 U.S. 1046 (1981); Burns v. Southern Pac. Transp. Co., 589 F.2d 403, 407 (9th Cir. 1978) ("In our view, the loss of dues [in the amount of $\$ 19$ per month] to the Union is de minimis, even if so necessary to its fiscal well-being that its equivalent would be collected from the Local's 300 members at a rate of 2 cents each per month."), cert. denied, 439 U.S. 1072 (1979); cf. Franks v. Bowman Transp. Co., 424 U.S. 747 (1976) (holding that trial courts may assign seniority rights to victims of an employer's illegal conduct).

119 See 3 LARSON, supra note $36, \$ 56.03$ [1] (finding co-employee discriminationdiscrimination against other employees whose shift preferences were based on nonreligious reasons-to be the primary rationale of Hardison).

${ }^{120}$ See Estate of Thornton v. Caldor, Inc., 472 U.S. 703, 711-12 (1985) (O'Connor, J., concurring) (observing that Title VII does not violate the Establishment Clause); cf. Protos v. Volkswagen of Am., Inc., 797 F.2d 129, 134 (3d Cir.) (noting that the Sabbatarian employee's demand for all Saturdays off from work was within the realm of reasonable-and constitutional-accommodation), cert. denied, 479 U.S. 972 (1986); EEOG v Ithaca Indus., Inc., 849 F.2d 116, 119 (4th Cir. 1988) (en banc) (same).

Since the low de minimis threshold remains for economic burdens faced by the employer, RFRA, in connection with Title VII, does not violate the Establishment Clause. Cf. Flores v. City of Boerne, 73 F.3d 1352, 1364 (5th Cir. 1996) (noting that RFRA does not violate the Establishment Clause since "it is a permissible legislative purpose to alleviate significant governmental interference' with the exercise of religion" (quoting Corporation of the Presiding Bishop v. Amos, 483 U.S. 327, 335 (1987))); Thornton, 472 U.S. at 703 (holding that a Connecticut statute violated the Establishment Clause because employers were forced to accommodate without regard to the burden or inconvenience on them). 
precedent affecting the Government's disbursement of unemployment benefits, would also help prevent the employee from losing her job and from needing unemployment benefits at all. 